\title{
Multivariate Genetic Divergence Studies in Brinjal (Solanum melongena L.)
}

\author{
Ram Ashish Gupta ${ }^{1}$, C.N. Ram ${ }^{1 *}$, Satish Kr. Chakravati ${ }^{2}$, Chandra Deo ${ }^{1}$, \\ M.K. Vishwakarma ${ }^{3}$, D.K. Gautam ${ }^{1}$, Pushpendra Kumar ${ }^{1}$ and Pratik Kumar ${ }^{1}$ \\ ${ }^{1}$ Department of Vegetable Science, (N.D.U.A \& T, Kumarganj, Faizabad U.P.), India \\ ${ }^{2}$ Krishi Vigyan Kendra, Bahraich (N.D.U.A \& T, Kumarganj, Faizabad U.P.), India \\ ${ }^{3}$ Department of Genetics and Plant Breeding, BHU, Varanasi, 221005, India \\ *Corresponding author
}

A B S T R A C T

\begin{abstract}
Keywords
Manalanobis $\mathrm{D}^{2}$

statistics' and

divergence in

brinjal (Solanum

melongena $\mathrm{L}$.)

Article Info

Accepted:

14 September 2017

Available Online:

10 October 2017

The present investigation was executed with the thirty-two genotypes of four groups including two checks (Arka Nidhi, and Mukta Keshi). On the basis, of multivariate analysis using Mahalanobis' D2-statistic employing ten quantitative characters viz. yield components and fruit yield could be grouped into 6 clusters. Cluster VI had the highest number of genotypes followed by clusters V, IV, and I. The intra-cluster $\mathrm{D}^{2}$ values ranged from 32.76 (cluster II) to 106.45 (cluster V). The maximum inter-cluster distance was observed between clusters I to cluster VI (483.21) suggested that genotypes of these clusters are genetically very diverse to each other. The crosses between selected genotypes from widely separated clusters are most likely to give desirable recombinants/hybrids in the future breeding program of brinjal.
\end{abstract}

\section{Introduction}

Brinjal or eggplant (Solanum melongena L.) is one of the significant Solanaceous principal vegetable crops cultivated in India. Mostly grown in both temperate and tropical regions of the globe mainly for its immature fruits as vegetables (Gupta et al., 2017). A good degree of diversity present among the genotypes of brinjal for different quantitative traits proposed beneficial scope for improvement in economic characteristics through mainstream breeding (Vidhya and Kumar, 2014).

In crop improvement program there are several techniques to identify suitable parents for the hybridization for the superior hybrids and desirable recombinants, where the genetic diversity plays a vital role as it helps in selecting the suitable parents (Kumar et al., 2016). Several techniques are present these days to assess the diversity among the genotypes and the contribution of each character to the total diversity, but out of all techniques, Mahalanobis $\mathrm{D}^{2}$ analysis is the most reliable and utilized (Rao, 1952; Saxesena et al., 2013). Greater the genetic distance better are the chances of obtaining desirable hybrids or segregates after hybridization between diverse groups. For grouping samples to obtain high level of 
homogeneity within each group and high heterogeneity between groups, $\mathrm{D}^{2}$ cluster analysis is adopted (Johnson and Wichern, 1982). The present research was designed to work out the kind of genetic divergence that exists among 32 genotypes based on ten important traits if brinjal.

\section{Materials and Methods}

The experiment was conducted in Randomized Complete Block Design with three replications during kharif season in 2014 to assess the performance of thirty-two genotypes. Each treatment consisted of two rows. Ten plants were maintained in each row and replicated thrice.

Transplanting was done at a spacing of $60 \mathrm{~cm}$ between row to row and $45 \mathrm{~cm}$ plant to plant having net plot size of $4.5 \times 1.2 \mathrm{~m}^{2}$. Observations were recorded on ten character $v i z$. days to $50 \%$ flowering, primary branches per plant, plant height $(\mathrm{cm})$, fruit weight $(\mathrm{g})$, fruit circumference $(\mathrm{cm})$, fruit length $(\mathrm{cm})$, fruits per plant, marketable fruit yield per plant $(\mathrm{kg})$, unmarketable fruit yield per plant $(\mathrm{kg})$ and total fruit yield per plant $(\mathrm{kg})$. The genetic divergence of thirty-two genotypes of brinjal was worked out using Mahalanobis (1928) $\mathrm{D}^{2}$ statistics.

\section{Results and Discussion}

The studies on genetic divergence among thirty-two genotype of brinjal were carried out by using Mahalanobis $\mathrm{D}^{2}$ statistics. In the present investigation, thirty-two genotypes of brinjal were grouped in ten distinct not overlapping clusters.

The Cluster VI had a maximum number of genotypes (11) followed by clusters V (7), IV (6), I (4), II (2), and cluster III (2) genotypes (Table 1). This indicated presence of considerable diversity in the genotypes. The major clusters in the above mentioned genetic divergence analysis frequently contained the genotypes of heterogeneous origin. Although the genotypes of the same origin or geographic region were also found to be grouped in the same cluster. The examples of the grouping of genotypes of different origin or geographic region in the same cluster were frequently observed. This suggested that there is no parallelism between genetic and geographic diversity.

The intra cluster $\mathrm{D}^{2}$ values ranged from 32.76 (cluster II) to 106.45 (cluster V). The maximum inter cluster distance was observed between cluster I and cluster VI (483.21) which suggested that members of these two clusters are genetically very diverse to each other. The inter clusters distance between cluster II and cluster VI (348.21), cluster IV to VI (313.15) and cluster V to VI (265.68) were very high.

The minimum inter cluster $\mathrm{D}^{2}$ value was recorded in case of cluster I and cluster IV (113.99) followed by cluster III and cluster IV (117.05) (Tables 2 and 3). The higher inter cluster distance indicated greater genetic divergence between the genotypes of these clusters, while lower inter cluster values between the clusters suggested that the genotypes of the clusters were not much genetically diverse from each other.

Cluster first showed maximum mean values for the days to $50 \%$ flowering whereas (Table 3 ); cluster VI had minimum mean values for fruit circumference followed by fruits per plant, average fruit weight, marketable fruit yield, total fruit yield and primary branches per plant contributed maximum towards total genetic divergence in the available genotypes of brinjal. The similar finding was also recorded by Thirumurugan et al., (1999); Bansal and Mehta (2007); Dutta et al., (2009) for genetic divergence in egg plant. 
Table.1 Clustering pattern of thirty two genotypes of brinjal on the basis of Mahalanobis $\mathrm{D}^{2}$ statistics

\begin{tabular}{|c|c|c|}
\hline Cluster number & No. of genotypes & Genotypes \\
\hline I & 4 & NDB-301, NDB-314, NDB-309, NDB-316 \\
\hline II & 2 & NDB-315, NDB-320 \\
\hline III & 2 & NDB-304, NDB-305 \\
\hline IV & 6 & NDB-306, NDB-318, NDB-310, NDB-312, NDB-311, NDB-319 \\
\hline $\mathrm{V}$ & 7 & NDB302, NDB-313, NDB-303, ArkaNidhi, NDB-317, NDB-307, NDB-308 \\
\hline VI & 11 & $\begin{array}{l}\text { NDB-321, NDB-330, NDB-325, NDB-324, NDB-327, NDB-327, MuktaKeshi, NDB-322, } \\
\text { NDB-328, NDB-323, NDB-329 }\end{array}$ \\
\hline
\end{tabular}

Table.2 Average intra and inter clusters $\mathrm{D}^{2}$ values for six clusters in brinjal germplasm

\begin{tabular}{|c|c|c|c|c|c|c|}
\hline Cluster number & Cluster-I & Cluster-II & Cluster-III & Cluster-IV & Cluster-V & Cluster-VI \\
\hline Cluster-I & 76.98 & 145.24 & 190.01 & 113.99 & 229.84 & 483.21 \\
\hline Cluster-II & & 32.76 & 165.57 & 127.04 & 150.56 & 348.03 \\
\hline Cluster-III & & & 79.76 & 117.05 & 229.37 & 226.88 \\
\hline Cluster-IV & & & & 41.62 & 165.26 & 313.15 \\
\hline Cluster-V & & & & & 106.45 & 265.68 \\
\hline Cluster-VI & & & & & & 92.39 \\
\hline
\end{tabular}

Table.3 Intra cluster group mean for ten characters in brinjal germplasm

\begin{tabular}{|c|c|c|c|c|c|c|c|c|c|c|}
\hline Characters & $\begin{array}{c}\text { Days to } \\
50 \% \\
\text { flowering }\end{array}$ & $\begin{array}{c}\text { Plant } \\
\text { height } \\
\text { (cm) }\end{array}$ & $\begin{array}{c}\text { No of } \\
\text { primary } \\
\text { branches } \\
\text { per } \\
\text { plant }\end{array}$ & $\begin{array}{c}\text { Fruit } \\
\text { length } \\
(\mathrm{cm})\end{array}$ & $\begin{array}{c}\text { Fruit } \\
\text { circumference } \\
(\mathbf{c m})\end{array}$ & $\begin{array}{c}\text { No of } \\
\text { fruits } \\
\text { per } \\
\text { plant }\end{array}$ & $\begin{array}{l}\text { Average } \\
\text { fruit } \\
\text { weight } \\
\text { (g) }\end{array}$ & $\begin{array}{c}\text { Marketable } \\
\text { fruit yield } \\
\text { per } \\
\text { plant(kg) }\end{array}$ & $\begin{array}{c}\text { Unmarketable } \\
\text { fruit yield per } \\
\text { plant (kg) }\end{array}$ & $\begin{array}{c}\text { Total fruit } \\
\text { yield per } \\
\text { plant(kg) }\end{array}$ \\
\hline Cluster-I & 53.41 & 73.06 & 4.70 & 15.63 & 11.01 & 15.52 & 126.29 & 1.87 & 0.16 & 2.03 \\
\hline Cluster-II & 42.50 & 70.56 & 4.56 & 18.28 & 13.68 & 21.38 & 103.71 & 1.96 & 0.20 & 2.16 \\
\hline Cluster-III & 52.66 & 60.93 & 4.52 & 15.86 & 17.98 & 13.38 & 127.08 & 1.37 & 0.13 & 1.69 \\
\hline Cluster-IV & 44.61 & 74.43 & 4.08 & 16.40 & 12.43 & 11.72 & 117.08 & 1.21 & 0.14 & 1.36 \\
\hline Cluster-V & 47.90 & 81.08 & 6.44 & 20.61 & 14.85 & 14.94 & 124.12 & 1.62 & 0.19 & 1.82 \\
\hline Cluster-VI & 50.03 & 79.76 & 5.19 & 15.99 & 22.80 & 11.96 & 194.77 & 2.07 & 0.22 & 2.31 \\
\hline
\end{tabular}


Table.4 Per cent contribution of ten characters towards total genetic divergence in brinjal

\begin{tabular}{clcc}
\hline S. No. & \multicolumn{1}{c}{ Source } & Times Ranked 1 $^{\text {st }}$ & Per cent contribution $^{-1}$ \\
\hline 1. & Days to 50\% flowering & 23 & 4.64 \\
2. & Plant height (cm) & 42 & 8.47 \\
3. & Number of primary branches per plant & 22 & 4.44 \\
4. & Fruit length $(\mathrm{cm})$ & 77 & 15.52 \\
$\mathbf{5 .}$ & Fruit circumference $(\mathrm{cm})$ & 244 & 49.19 \\
$\mathbf{6 .}$ & Number of fruits per plant & 54 & 10.89 \\
$\mathbf{7 .}$ & Average fruit weight $(\mathrm{g})$ & 2 & 0.40 \\
$\mathbf{8 .}$ & Marketable fruit yield per plant $(\mathrm{kg})$ & 1 & 0.20 \\
$\mathbf{9 .}$ & Unmarketable fruit yield per plant $(\mathrm{kg})$ & 28 & 5.65 \\
$\mathbf{1 0 .}$ & Total fruit yield per Plant $(\mathrm{kg})$ & 3 & 0.60 \\
\hline
\end{tabular}

A perusal of Table 4 showed that marketable, average fruit weight and total fruit yield per plant contributed very low towards the divergence while fruit circumference was found for highest contribution (49.19\%) followed by Polar length of fruit (15.52) and primary branches per plant (10.89) for total divergence among the available genotypes of brinjal.

\section{Acknowledgment}

The work on brinjal reported in this paper has been supported by research and teaching faculties of Department of Vegetable Science, N.D.U.A.T. Faizabad, Uttar Pradesh.

\section{References}

Bansal, S., and Mehta, A. K. 2007. Genetic divergence in brinjal (Solanum melongena L.). Haryana J. Hort. Sci., 36 (3/4): 319-320.

Dutta, R., Mandal, A. K., Maity, T. K. and Hazra, P. 2009. Multivariate genetic divergence in brinjal (Solanum melongena L.). J. Crop and Weed, 5 (1): 67-70.

Gupta R. A., Ram C. N., Chakravati S. K., Deo C., Vishwakarma, M. K., Gautam, D. K. and Kumar, P. 2017. Studies on Correlation and Path Coefficient Analyses in Brinjal
(Solanum melongena L.) Int.J.Curr.Microbiol.App.Sci, 6(7): 45434548.

Johnson, R.A., and Wichern, D.W. 1982. Applied Multivariate Statistics Analysis pp 320.

Kumar, R., Sirohi, A., Chakravarti, S. K., Chaudhary, N. K. and Vishwakarma, M. K. 2016. Analysis of genetic diversity in north Indian rice (Oryza sativa L.) Germplasm, using SSR and ISSR markers. Romanian Agricultural Research, 33, 13-21.

Mahalanobis, P.C., 1928. On the generalized distance in statistics. Proc. Nat. Inst. Sci. India., 2:49-55.

Prentice-Hall, New Jersey.

Rao, C.R., 1952. Advanced Statistical Methods in Biometrical Research. John Wiley \& Sons, New York. pp 390

Saxesena, R. R., Lal, G. M., Yadav, P. S. and Vishwakarma, M. K. 2013. Diversity analysis and identification of promising lines forhybridization in field pea (Pisum sativum L.). The Bioscan, 8 (4): 1337-1340.

Thirumurugan, T., Babu, S., Sassikumar, D. and Ganesan, J. 1999. Genetic divergence analysis in eggplant (Solanum melongena L.). Tropical Agric. Res., 11:143-148.

Vidhya, C., and Kumar, N. 2014. Genetic Divergence in Brinjal (Solanum melongena L.) The Ecoscan, 6: 197-200.

\section{How to cite this article:}

Ram Ashish Gupta, C.N. Ram, Satish Kr. Chakravati, Chandra Deo, M.K. Vishwakarma, D.K. Gautam, Pushpendra Kumar and Pratik Kumar. 2017. Multivariate Genetic Divergence Studies in Brinjal (Solanum melongena L.). Int.J.Curr.Microbiol.App.Sci. 6(10): 1370-1373.

doi: https://doi.org/10.20546/ijcmas.2017.610.161 